\title{
Lanthanide-Doped Upconversion Nanocarriers for Drug and Gene Delivery
}

\author{
Gibok Lee (1) and Yong Il Park * (1) \\ School of Chemical Engineering, Chonnam National University, Gwangju 61186, Korea; 188608@jnu.ac.kr \\ * Correspondence: ypark@jnu.ac.kr; Tel.: +82-62-530-1886; Fax: +82-62-530-1889
}

Received: 4 June 2018; Accepted: 7 July 2018; Published: 9 July 2018

\begin{abstract}
Compared to traditional cancer treatments, drug/gene delivery is an advanced, safe, and efficient method. Nanoparticles are widely used as nanocarriers in a drug/gene delivery system due to their long circulation time and low multi-drug resistance. In particular, lanthanide-doped upconversion nanoparticles (UCNPs) that can emit UV and visible light by near-infrared (NIR) upconversion demonstrated more efficient and safer drug/gene delivery. Because of the low penetration depth of UV and visible light, a photoinduced reaction such as photocleavage or photoisomerization has proven restrictive. However, NIR light has high tissue penetration depth and stimulates the photoinduced reaction through UV and visible emissions from lanthanide-doped UCNPs. This review discusses the optical properties of UCNPs that are useful in bioapplications and drug/gene delivery systems using the UCNPs as a photoreaction inducer.
\end{abstract}

Keywords: upconversion nanoparticles; nanocarriers; drug delivery; gene delivery; photolysis

\section{Introduction}

Cancer is one of the major diseases that threatens human health worldwide. Many researchers have developed various cancer treatments such as surgery, chemotherapy, and radiotherapy. However, these methods have limitations. Because cancer lesions and normal tissue are not completely differentiated during surgery, large complex tissues are removed. Chemotherapy works on the whole body in addition to the cancerous tissues and results in low tumor-specific targeting, severe side effects, drug dependence, and multi-drug resistance (MDR) [1-4]. Radiotherapy works on a specific region with normal tissues and results in skin damage, cancer recurrence, cell mutation, dose-dependent side effects, and cardiovascular problems [5-7]. Therefore, the development of more efficient and safe methods to remove cancerous tissues is essential for improving cancer treatments. Recently, drug/gene delivery systems have been suggested as an alternative to conventional cancer treatments. In particular, nanoparticles used as drug/gene carriers are attracting attention due to advantages such as their high tumor-specific targeting with low side effects and increased loading capacity. Nanoparticles tend to accumulate in tumor lesions through the relatively leaky tumor vasculature, and this accumulation is associated with the enhanced permeability and retention (EPR) effect [8-11]. The large specific surface area of nanoparticles and mesoporous/hollow nanostructures increases the amount of drug/gene loading. To exploit these advantages, many researchers have designed nanocarriers such as liposomes [12-15], polymeric micelles [16-18], polymeric nanoparticles [19-21], carbon nanotubes [22,23], reduced graphene oxides [24-26], gold nanoparticles [27-29], magnetic nanoparticles [30-32], and lanthanide-doped upconversion nanoparticles (UCNPs) [33-38].

In this review, we discuss drug/gene delivery systems that use lanthanide-doped UCNPs. The unique and fascinating optical properties that convert near-infrared (NIR) light to visible and UV light allow UCNPs to be used as more efficient nanocarrier materials in drug/gene delivery systems. This drug/gene delivery system is based on photoinduced reactions such as photocleavage 
and photoisomerization. Photoinduced delivery systems enhance the efficacy of spatial and temporal control of drug/gene release and minimize normal cell death, side effects, and the tissue damage.

\section{Lanthanide-Doped UCNPs}

Photoinduced drug/gene delivery systems use photoreactions to control drug release and gene expression, mainly through UV light sources. However, the UV region is not only harmful to tissues and cells, but also has a disadvantage of low tissue penetration depth due to its absorption by biological substances (e.g., protein, hemoglobin, and melanin) [39,40]. Unlike UV light, NIR light exhibit the deep penetration depth due to low absorption by biological substances and minimizes photodamage to tissues and cells [39,41]. In order to use NIR light for photoinduced drug/gene delivery, an anti-Stokes shifting material that emits UV light by NIR excitation is required. Among the various materials, UCNPs have been proposed as a strong candidate. Upconversion is the process by which multiple lower energy photons are converted to higher energy photons and are emitted [42]. Various lanthanide-doped UCNPs have been extensively investigated, and ytterbium $\left(\mathrm{Yb}^{3+}\right)$, erbium $\left(\mathrm{Er}^{3+}\right)$, thulium $\left(\mathrm{Tm}^{3+}\right)$, and holmium $\left(\mathrm{Ho}^{3+}\right)$ are well-known lanthanide dopants in UCNPs (see Figure 1a) [43]. $\mathrm{Yb}^{3+}$ ions are usually used as a sensitizer for absorbing NIR photons, and $\mathrm{Er}^{3+}, \mathrm{Tm}^{3+}$, and $\mathrm{Ho}^{3+}$ ions are used as an activator to emit upconverted luminescence (i.e., visible and UV). In addition, because lanthanide ions produce long-lived luminescence emission through the forbidden $4 \mathrm{f}-4 \mathrm{f}$ transition between real intermediate energy states, upconversion is much more efficient than other anti-Stokes shift phenomena (e.g., two-photon absorption and second harmonic generation). Moreover, compact and inexpensive continuous wave (CW) lasers can be used as an excitation source for upconversion, while other anti-Stokes shifting materials require high power pulsed lasers [44,45]. Since energy transfer between the energy levels of lanthanide ions is possible, the choice of UCNP host material doped with lanthanide elements has a significant effect on the upconversion mechanism and its efficiency. The most widely used host material for lanthanide-mediated upconversion is sodium yttrium fluoride $\left(\mathrm{NaYF}_{4}\right)$ because of its relatively low phonon energy $\left(400 \mathrm{~cm}^{-1}\right)$, which minimizes non-radiative relaxation decay $[46,47] . \mathrm{Yb}^{3+}$ and $\mathrm{Er}^{3+}$ co-doped UCNPs are primarily used as probes for in vitro and in vivo bioimaging [48-50]. The ${ }^{2} \mathrm{H}_{11 / 2},{ }^{4} \mathrm{~S}_{3 / 2} \rightarrow{ }^{4} \mathrm{I}_{15 / 2}$, and ${ }^{4} \mathrm{~F}_{9 / 2} \rightarrow{ }^{4} \mathrm{I}_{15 / 2}$ transitions in trivalent $\mathrm{Er}^{3+}$ emit the green and red upconverted luminescence (see Figure 1b) [51]. Green emission from $\mathrm{Yb}^{3+}$ and $\mathrm{Er}^{3+}$ co-doped UCNPs shows relatively high quantum yield compared to UCNPs with other lanthanide elements [52-54]. $\mathrm{Yb}^{3+}$ and $\mathrm{Tm}^{3+}$ co-doped UCNPs are primarily used as UV sources for photoinduced reactions. The ${ }^{1} \mathrm{I}_{6} \rightarrow{ }^{3} \mathrm{H}_{6},{ }^{1} \mathrm{D}_{2} \rightarrow{ }^{3} \mathrm{H}_{6},{ }^{1} \mathrm{D}_{2} \rightarrow{ }^{3} \mathrm{~F}_{4}$, and ${ }^{1} \mathrm{G}_{4} \rightarrow{ }^{3} \mathrm{H}_{6}$ transition in trivalent $\mathrm{Tm}^{3+}$ emit the UV and blue upconverted luminescence (see Figure 1b) [51]. Thus, $\mathrm{Yb}^{3+}$ and $\mathrm{Tm}^{3+}$ co-doped UCNPs can induce photocleavage and photoisomerization of photosensitive compounds for drug/gene delivery systems. 
(a)

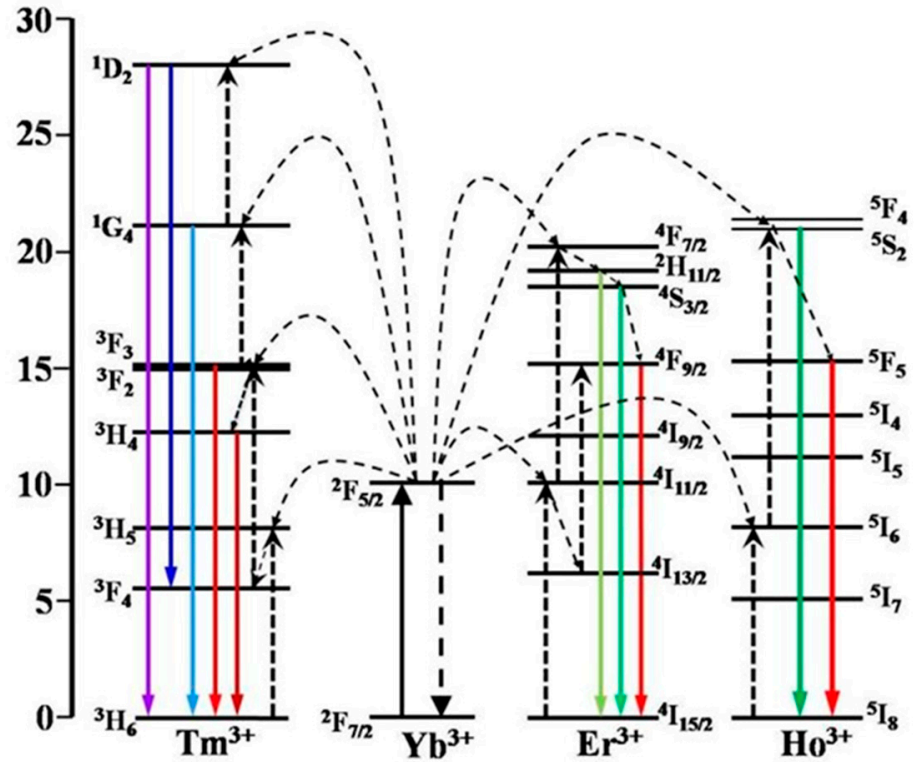

(b)

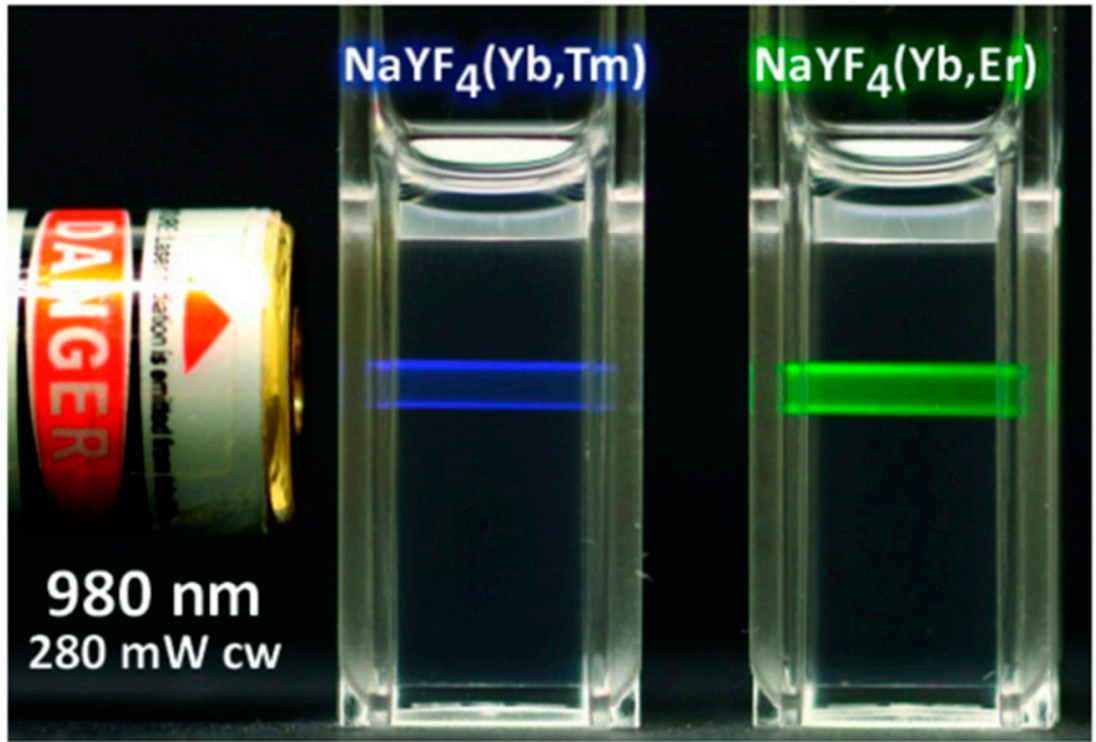

Figure 1. (a) Energy level diagrams of $\mathrm{Tm}^{3+}, \mathrm{Yb}^{3+}, \mathrm{Er}^{3+}$, and $\mathrm{Ho}^{3+}$ ions, illustrating the upconversion mechanism in lanthanide-doped upconversion nanoparticles (UCNPs) [43]. (b) Photographs of upconversion emission excited by a $980 \mathrm{~nm}$ laser [51]. Reproduced with permission from [43]. Copyright MDPI, 2017. Reproduced with permission from [51]. Copyright IVYSPRING, 2013.

Figure 2a shows the difference in the penetration depths of UV and NIR light through pork skin placed on top of a solution containing UCNPs [55]. Figure $2 b$ shows the penetration difference between UV and NIR lasers used to excite the fluorescein (FITC) and UCNPs, respectively. Under UV irradiation, the emission intensity from FITC decreased when the thickness of chicken breast increased, but the fluorescence signal from FITC was not observed when the thickness of chicken breast reached $6 \mathrm{~mm}$. Under NIR irradiation, however, enough photons are transmitted to the UCNPs to emit green luminescence even though the thickness of the chicken is $10 \mathrm{~mm} \mathrm{[56].} \mathrm{Also,} \mathrm{the} \mathrm{penetration} \mathrm{depth} \mathrm{of}$ NIR light for upconversion imaging was demonstrated to be 1.25 inches $(3.2 \mathrm{~cm})$ at the pork tissue [57]. Therefore, UCNPs can be used as effective UV sources that can cause photoinduced reactions under NIR irradiation with high penetration depth and can be used as nanocarriers for drug/gene delivery. 
(a)

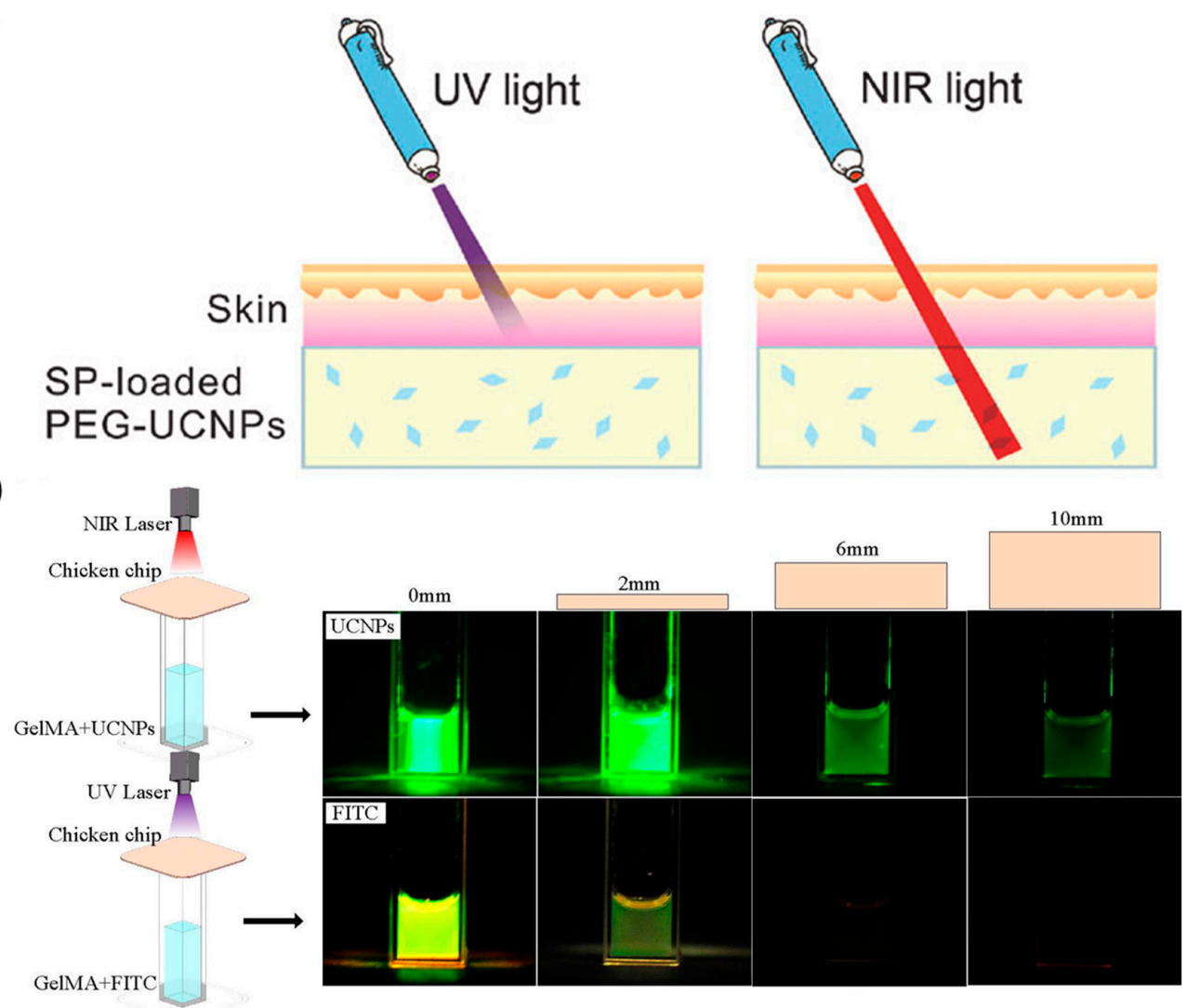

Figure 2. (a) Illustration of the penetration depths for UV and NIR light [55]. (b) Photographs of tissue penetration for NIR and UV light. Slices of chicken breast with various thicknesses ( $2 \mathrm{~mm}-10 \mathrm{~mm})$ were placed between the laser source and the glass cuvette containing the UCNP-labeled hydrogel and fluorescein (FITC)-labeled hydrogel, respectively [56]. Reproduced with permission from [55]. Copyright The Royal Society of Chemistry, 2015. Reproduced with permission from [56]. Copyright Elsevier, 2017.

\section{Drug/Gene Delivery Using Photocleavage}

In drug/gene delivery, the photocleavage reaction of small molecules or polymer backbones is an attractive method to trigger drug release and gene expression. The photocleavage reaction has three methods, namely (1) the direct cleavage of the bond between the molecule and the carrier [37,58-60]; (2) a change in the charge on the carrier surface used to induce electrostatic repulsion between the molecules and the carrier [61,62]; and (3) the destruction of the carrier itself [63].

\subsection{Direct Cleavage of the Bond between the Molecule and the Carrier}

The photosensitive compounds are modified to bind the drug/gene to the carrier through a variety of molecular interactions, thus undergoing irreversible deformation $[37,58,60,64,65]$. The most commonly used photosensitive molecules are coumarinyl and o-nitrobenzyl esters. They serve as linkers that bind the drug/gene to the carriers and are broken when exposed to UV or visible light. These photoreactive molecules can also be directly destroyed by two-photon absorption of NIR light $[66,67]$. However, the molecules have a small two-photon absorption cross-section and slow reaction rate [68]. Thus, this photoreaction involving two-photon absorption requires a higher NIR laser power and longer reaction time than a UV (or visible) source. Due to the NIR excitation and efficient upconverted UV and visible light emission, the UCNPs can be used to induce photocleavable reactions using NIR light. When combined with the high penetration depth of NIR light, the low energy requirement of the UCNPs, which can be used with inexpensive CW lasers instead of high 
energy pulsed lasers, also has the advantage of increasing the delivery efficiency [69]. In 2015, He et al. reported that the UCNPs could induce photoreactive drug delivery under ultralow-intensity NIR irradiation [70]. The authors used the photocleavable reaction of the Ru complex to release the drug from the carrier (see Figure 3a). Since the absorption $(\sim 453 \mathrm{~nm})$ of the Ru complex overlaps with the blue emission from the UCNPs, the upconverted light by NIR excitation induces photocleavage of the Ru complex [71]. The mesoporous silica shell of the UCNPs $\left(\mathrm{UCNP} @ \mathrm{mSiO}_{2}\right)$ was used as the drug carrier, and the Ru complex was attached to the pores to serve as a molecular valve. Without NIR irradiation, the release of doxorubicin from $\mathrm{UCNP}_{\mathrm{mSiO}}$ was not detected. When irradiated with NIR light, doxorubicin clogged with the Ru complex in the UCNP@ $\mathrm{mSiO}_{2}$ was released due to photocleavage of the Ru complex (see Figure 3b). Irradiation with $0.35 \mathrm{~W} \mathrm{~cm}^{-2}$ laser intensity was sufficient to trigger the UCNPs-assisted photoreaction and release doxorubicin. Figure $3 \mathrm{c}$ also shows how the drug release efficiency depends on the NIR laser output intensity. Approximately $78 \%$ of the doxorubicin was released under irradiation with $0.64 \mathrm{~W} \mathrm{~cm}^{-2}$ for $5 \mathrm{~h}$, while $\sim 42 \%$ of the doxorubicin was released under irradiation with $0.35 \mathrm{~W} \mathrm{~cm}^{-2}$ for $5 \mathrm{~h}$. Direct cleavage of the photosensitive compound for the drug release is dependent on the irradiated laser power and irradiation time.

(a)

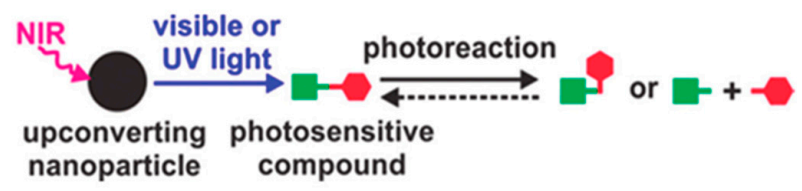

(b)
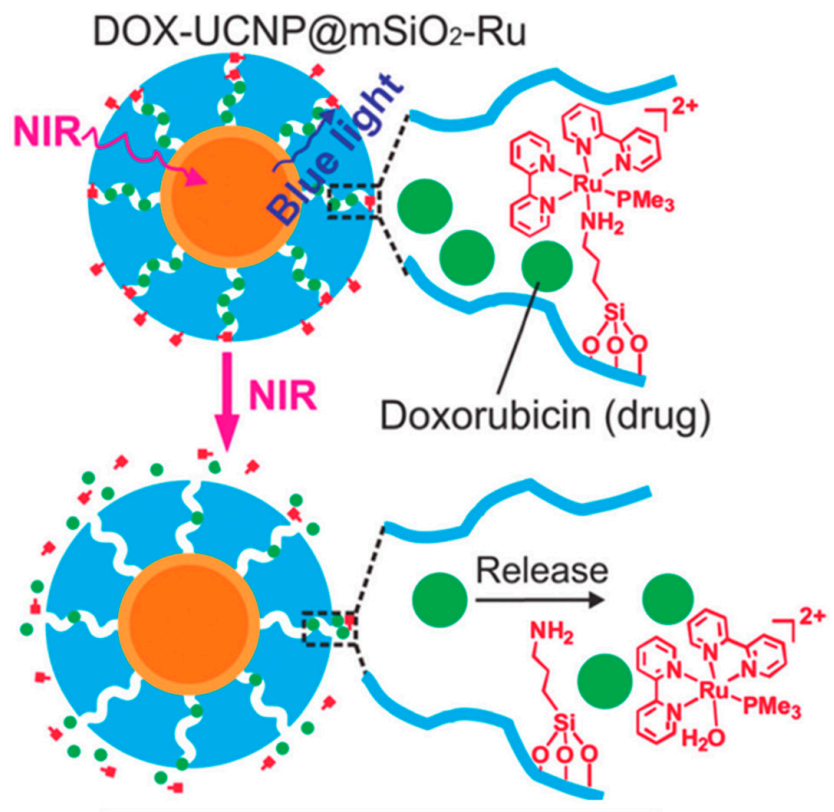

(c)

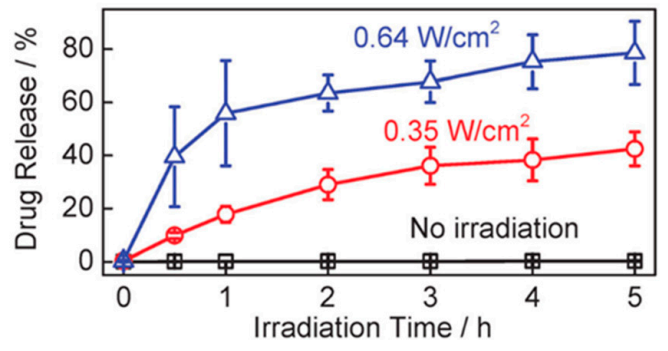

Figure 3. (a) Schematic illustration of photoreactions involving photosensitive compounds induced by UV and visible light produced by upconverted NIR radiation. (b) Under NIR irradiation, upconverted blue light triggers cleavage of the Ru complexes and drug release. (c) Doxorubicin release profiles with laser power and irradiation time. Reproduced with permission from [70]. Copyright The Royal Society of Chemistry, 2015. 


\subsection{Change in the Charge on the Carrier Surface To Induce Electrostatic Repulsion}

The delivery of chemical drugs enables effective therapy whether the carriers internalize into a cell or not. Contrary to chemical drug delivery, the carriers containing gene expression molecules must be internalized into a cell for gene therapy [72,73]. In addition, if the payload leakage is severe, the efficacy of gene therapy is greatly reduced. Therefore, the size and surface charge of the nanocarriers are important for cellular uptake. In particular, the positively charged surface of the nanocarriers demonstrates the increased efficiency of gene loading as well as an increased binding capacity to the anionic plasma membranes. The Fan group reported NIR-induced charge-variable cationic conjugated polyelectrolyte brushes (CCPEB) that encapsulate UCNPs for promoted siRNA release and cooperative photodynamic therapy (PDT) [61]. The charge-variable cationic conjugated polyelectrolyte (CCPE) was synthesized based on the $o$-nitrobenzyl ester and changed the surface charge on the carrier via the photocleavage reaction (see Figure 4a). CCPE has many positively charged quaternary amine groups that act as negatively charged nucleic acid carriers. The release of $o$-nitrobenzyl aldehyde by NIR irradiation converts the CCPEB on the UCNPs to zwitterionic conjugated polyelectrolyte brushes (ZCPEB) and initiates siRNA release by charge repulsion (see Figure 4b). As a result, UCNP@CCPEB as an siRNA carrier promoted siRNA release (80\% efficiency) at pH 5.0 under $980 \mathrm{~nm}$ irradiation.

(a)

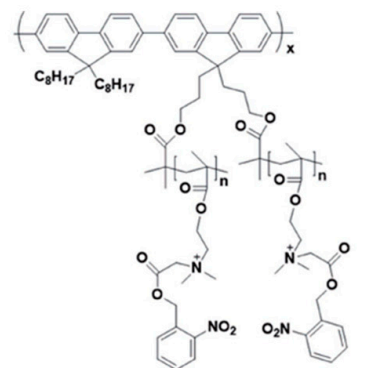

(CCPEB)

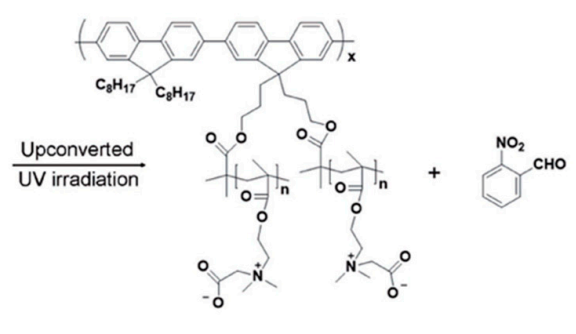

(ZCPEB)

(b)

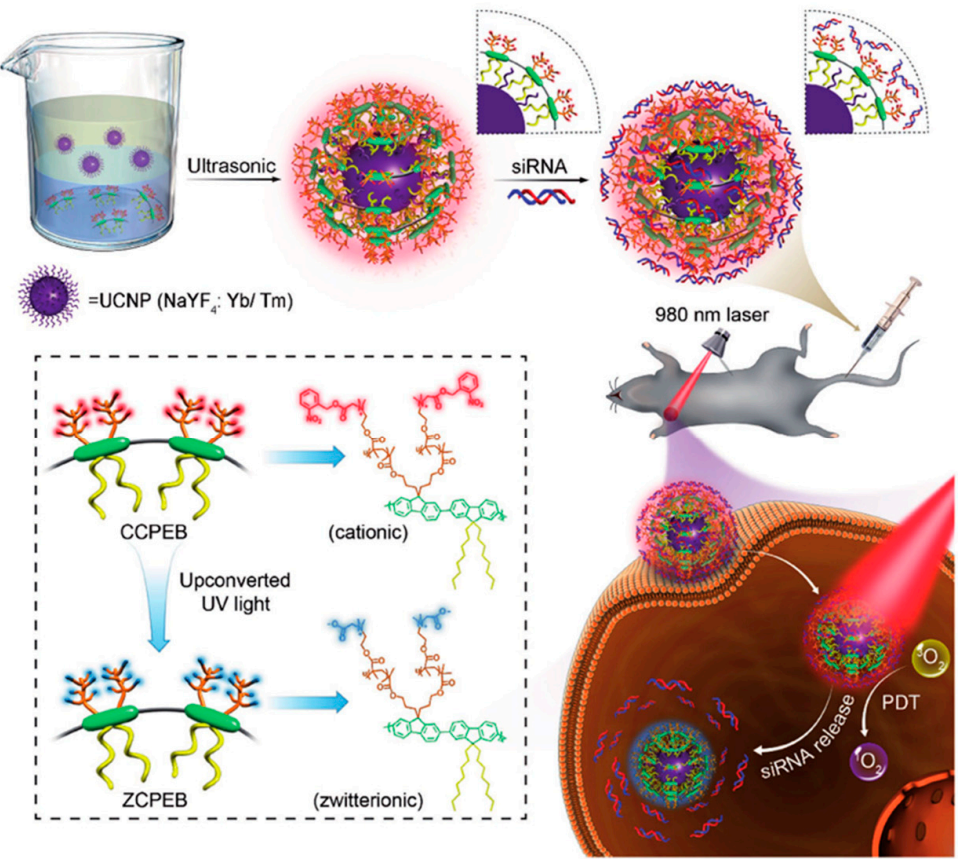

Figure 4. (a) Photoinduced charge-variable cationic conjugated polyelectrolyte brush (CCPEB). (b) Schematic representation of the NIR-induced charge-variable nanotherapeutic system (UCNP@CCPEB) for siRNA delivery and PDT. Reproduced with permission from [61]. Copyright John Wiley and Sons, 2017. 


\subsection{Destruction of the Carrier}

The nanocomposites encapsulating the drug molecules and functionalized nanomaterials increase the payload for effective chemotherapy. This strategy has the advantage of creating multifunctional materials by adding nanomaterials with various properties to the inside of the carrier. For example, UV emission from the UCNPs can destroy the drug carrier itself. In 2011, Yan et al. reported NIR light-triggered dissociation of block copolymer (BCP) micelles containing hydrophobic drugs and UCNPs (see Figure 5a) [63]. When the UCNPs in the BCP micelle were irradiated with NIR light, the polymethacrylate block in the BCP micelle was converted to hydrophilic poly-(methacrylic acid) by photocleavage of the hydrophobic $o$-nitrobenzyl groups (see Figure $5 \mathrm{~b}$ ). This collapse of the hydrophilic-hydrophobic balance destabilizes the BCP micelles [67]. Dissociation of the BCP micelles was also confirmed using TEM analysis. Before NIR irradiation, the BCP micelles contained 4-5 UCNPs per micelle (see Figure 5c). After excitation at $980 \mathrm{~nm}$, the BCP micelles completely collapsed, and the UCNPs and drugs were released from the micelles (see Figure 5d).

(a) NIR $(980 \mathrm{~nm})$
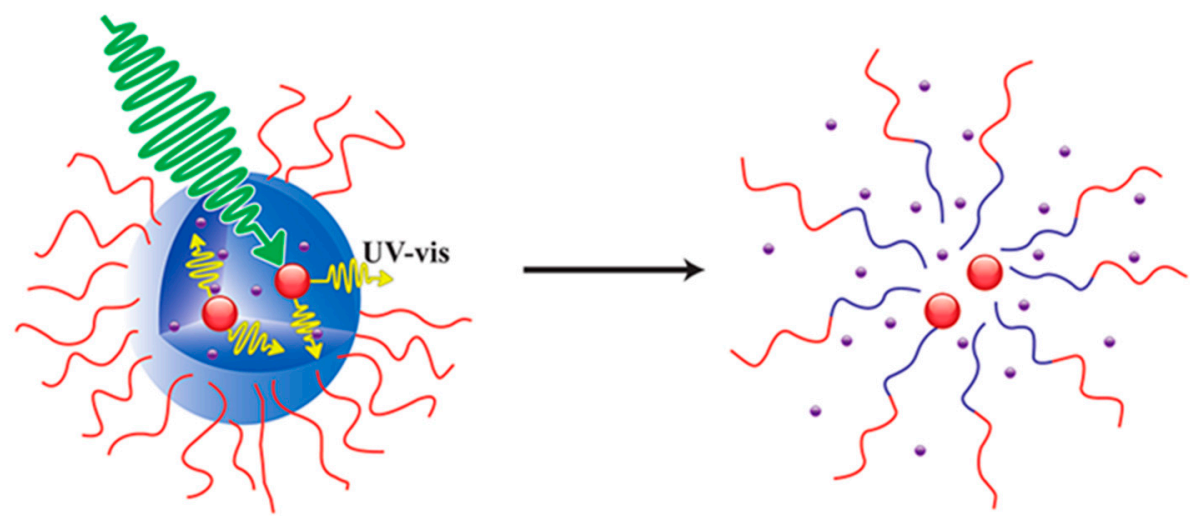

(b)
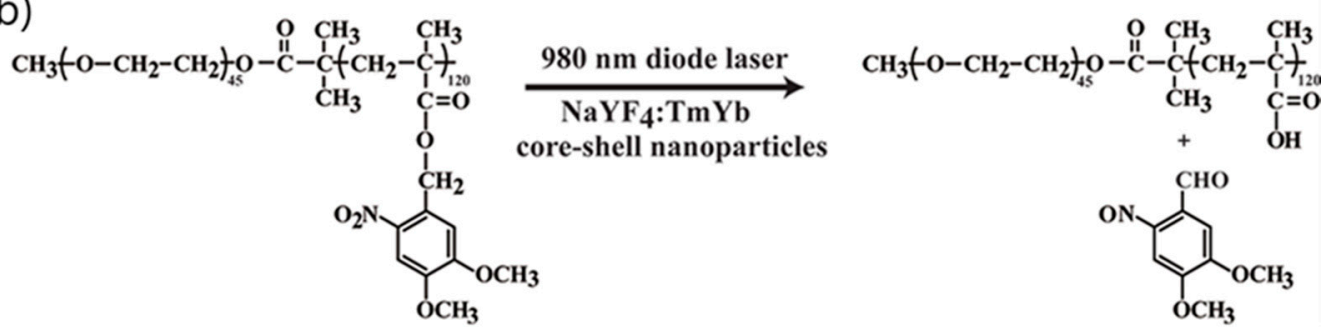

(c)

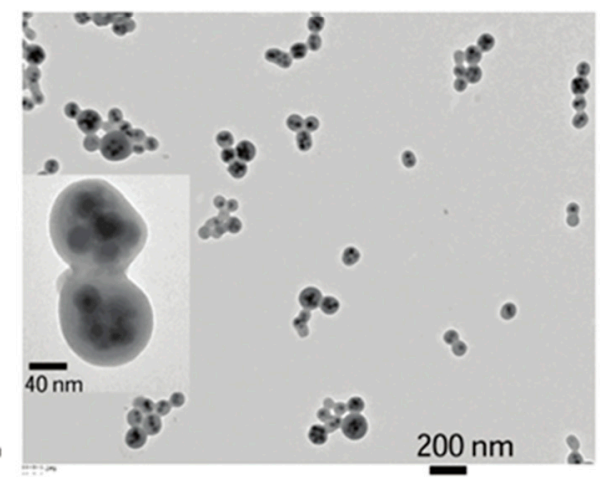

(d)

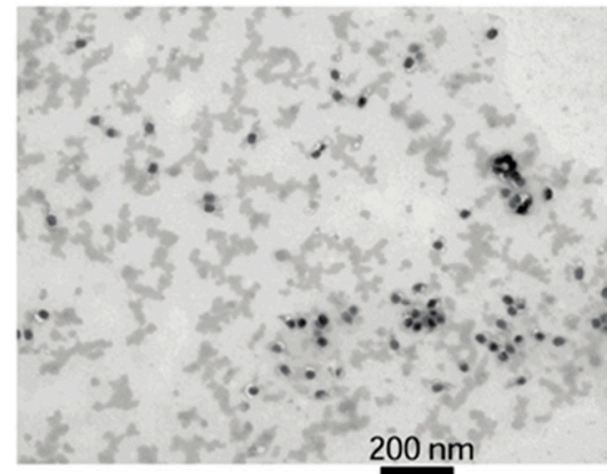

Figure 5. (a) Schematic of drug release resulting from NIR light-triggered dissociation of UCNP-loaded block copolymer (BCP) micelles. (b) Photoreaction scheme showing cleavage of the BCP backbone by NIR irradiation. (c,d) TEM images of the UCNP-loaded BCP micelles (c) before and (d) after NIR light irradiation. Reproduced with permission from [63]. Copyright American Chemical Society, 2011. 


\section{Drug/Gene Delivery Using Photoisomerization}

Photoisomerization is a reaction in which isomers change their spatial conformation under optical irradiation [74-77]. Molecules such as azobenzene, spiropyran, and dithienylethene are mainly used, and their spatial conformation changes reversibly under UV and visible illumination $[67,78]$. This reaction can be used as a switch to control the drug/gene release by opening the pathway through which the drug/gene passes. In particular, azobenzene with a trans-cis transformation is mainly used for lanthanide-doped UCNPs [79-83]. In 2016, Yao et al. developed azobenzene-liposome/UCNPs hybrid vesicles for controlled drug delivery to overcome cancer MDR [79]. Azobenzene liposomes (Azo-Lipo) consists of 1,2-distearoyl-sn-glycero-3-phosphocholine (DSPC) phospholipids and azobenzene amphiphilic derivatives. The as-synthesized hydrophobic UCNPs ( $\left.\mathrm{NaGdF}_{4}: \mathrm{Yb}, \mathrm{Tm} @ \mathrm{NaGdF}_{4}\right)$ were encapsulated by DSPC phospholipids via van der Waals interaction to induce a hydrophilic surface [84]. The hydrophilic UCNPs and doxorubicin are located in the hydrophilic cavity of the vesicles along with formation of the doxorubicin-loaded Azo-Lipo/UCNPs hybrid vesicles. UV and visible light from the UCNPs enable reversible photoisomerization of the azobenzene derivatives. Continuous rotation-inversion motion by reversible trans-cis conversion destabilizes the lipid bilayer and releases the drug (see Figure 6a). This nanocomposite showed increased drug release efficiency with higher laser power and increased concentration of azobenzene derivatives. The release of doxorubicin reached $57 \mathrm{wt} \%$ in $6 \mathrm{~h}$ under intermittent $2.2 \mathrm{~W} \mathrm{~cm}^{-2} \mathrm{NIR}$ laser irradiation, while over $90 \mathrm{wt} \%$ release can be reached in $6 \mathrm{~h}$ under intermittent $7.8 \mathrm{~W} \mathrm{~cm}^{-2}$ irradiation. The trans-cis transformation of azobenzene for drug release was also adapted to the mesopore structure on the UCNPs. In 2013, Liu et al. reported NIR-triggered anticancer drug delivery by UCNPs with an integrated azobenzene-modified mesoporous silica shell (Dox-UCNP@mSiO ${ }_{2}$-azo) [80]. The back and forth wagging motion of the azobenzene groups through trans-cis isomerization under UV and visible illumination acts as a molecular impeller to propel the release of doxorubicin from silica mesopores (see Figure 6b). Because the azobenzene molecular impeller is activated by light emitted from the UCNPs, drug release also depends on the laser power and duration. More doxorubicin was released with higher NIR illumination intensity. Conventional mesoporous silica releases the loaded drug by diffusion, the azobenzene impeller, regulated by the NIR light, controls the drug release more precisely. The azobenzene trans-cis transformation property has also been studied for use in gene delivery [85-88]. In 2017, Chen et al. reported an NIR-induced UCNP-based siRNA nanocarrier that exhibited spatiotemporally controlled gene silencing [81]. The UCNPs functionalized with $\beta$-cyclodextrin (CD) form the (UCNP-(CD/Azo)-siRNA) complex with siRNA-azobenzene through a host-guest interaction. Trans-azobenzene derivatives have a strong host-guest interaction with CD $[77,89]$. Under NIR irradiation, UV emission from the UCNPs induces photoisomerization of Azo-siRNAs into the cis configuration. The isomerized cis-azobenzene derivatives exhibit polarity change and steric hindrance, which destabilizes the host-guest interaction and releases siRNA (see Figure 6c). The amount of released siRNA can be easily controlled by selecting an appropriate NIR irradiation time. About $41 \%$ and $85 \%$ of siRNA was released within 10 and 20 min under $0.75 \mathrm{~W} \mathrm{~cm}^{-2} \mathrm{NIR}$ irradiation, respectively. In addition, spatial gene silencing was controlled by spatial irradiation in the cell culture dish. Cells which are half-covered by aluminum foil and irradiated with the NIR laser $\left(0.75 \mathrm{~W} \mathrm{~cm}^{-2}, 10 \mathrm{~min}\right)$ show region-specific down-regulation of green fluorescent proteins. This controlled drug/gene delivery shows that the NIR-activated UCNPs are safer and more efficient carriers. 
(c)

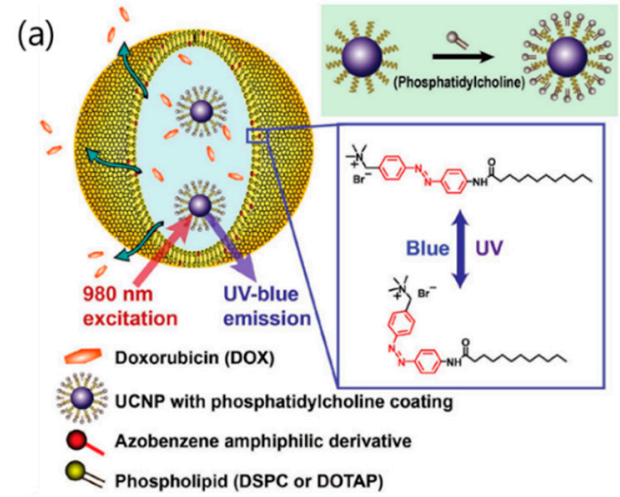

(a)

c)

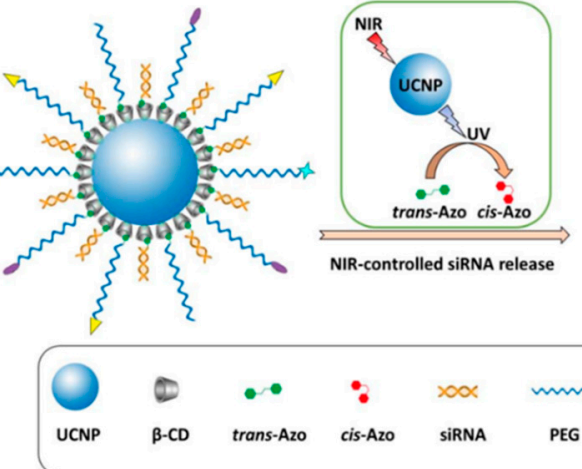

(b)
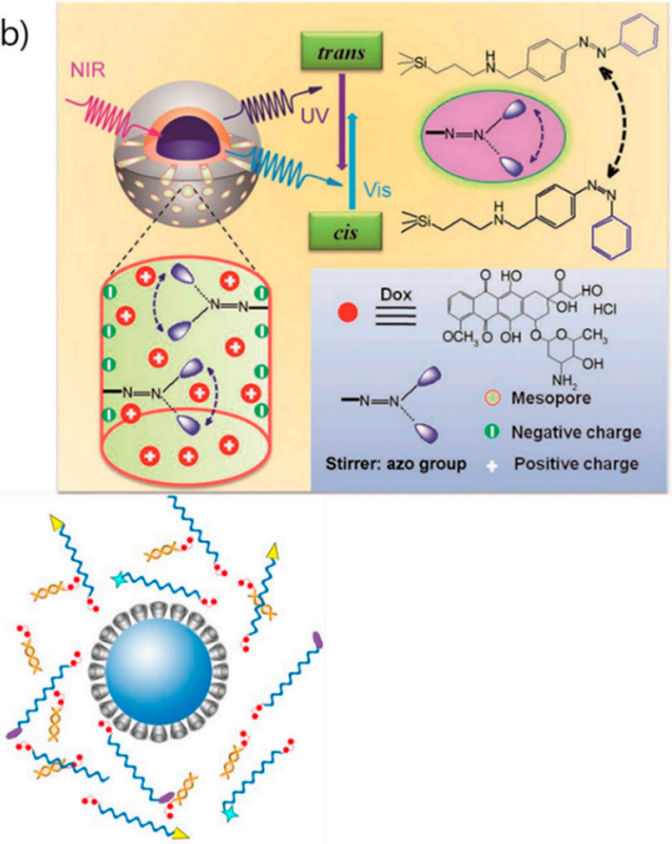

ligand

Figure 6. (a) Schematic illustration showing NIR light-triggered drug release of azobenzene-liposome/ UCNPs hybrid vesicles by trans-cis photoisomerization [79]. (b) NIR-activated drug release from azo molecules grafted on mesopores by trans-cis photoisomerization [80]. (c) Illustration of NIR-triggered trans-to-cis photoisomerization of azobenzene, which subsequently leads to siRNA release from the UCNP-(CD/Azo)-siRNA [81]. Reproduced with permission from [79]. Copyright John Wiley and Sons, 2016. Reproduced with permission from [80]. Copyright John Wiley and Sons, 2013. Reproduced with permission from [81]. Copyright Elsevier, 2018.

\section{Conclusions and Future Prospects}

The optical properties of lanthanide-doped UCNPs, which emit UV and visible light under NIR excitation, are useful for biomedical applications such as bioimaging and drug/gene delivery. In drug/gene delivery systems, UCNPs act as a source of UV light that cleaves the chemical link between the drug/gene and the nanocarrier and induces the photoisomerization of photosensitive compounds. The photocleavage of the photosensitive compound occurs by the direct cleavage of conjugation, a change in the charge on the surface of the carrier, and the destruction of the carrier itself. The photoreaction also depends on the NIR laser output power and irradiation time, resulting in better control over drug/gene release. Photoisomerization induces conformational change of the isomer. Azobenzene derivatives have been widely used as a photoisomer. These UCNPs generate a rapid release of the drug/gene for cancer treatment. In addition, the UCNPs function as a UV source and allow spatial control of gene expression by blocking the irradiating area. Despite the development of drug/gene delivery systems using lanthanide-doped UCNPs, several problems remain. Drug/gene payload is important for effective therapy and successful gene expression. However, a constraint of the payload in nanocarriers limits the therapeutic efficacy of the drug/gene delivery system. Increasing the concentration of nanocarriers induces high toxicity in normal tissues. Thus, to overcome these limitations, further studies on drug/gene delivery systems that combine immunotherapy [90] or other therapies, such as photodynamic therapy (PDT) [91,92] or photothermal therapy (PTT) [93], have been reported. Researchers should also investigate and understand the leakage of drugs/genes from the cargo to prevent side effects. For example, Bazylińska et al. reported that the leakage of delivery cargo 
was prevented by encapsulating the drug and UCNPs using the double emulsion method, which forms hybrid nanocomposites [94,95]. Future research should be carried out to reduce the loss of therapeutic agents as well as the leakage of inorganic species by utilizing lanthanide-doped UCNPs as nanocarriers. In particular, dissociation of the carrier itself releases all components such as drug/gene molecules, lanthanide-doped UCNPs, and enveloping molecules. This release can interrupt metabolism and excretion behavior. Thus, future research should investigate the toxicity of the residue by long-term tracking for the biosafety of nanocomposites.

Author Contributions: G.L. and Y.I.P. outlined and mainly wrote the manuscript. All authors contributed to discussion and reviewed the manuscript.

Funding: This work was supported by the National Research Foundation of Korea (NRF) grant funded by the Korea Government (Ministry of Science, ICT \& Future Planning) (No. 2016R1A4A1012224).

Conflicts of Interest: The authors declare no conflict of interest.

\section{References}

1. Chabner, B.A.; Roberts, T.G., Jr. Chemotherapy and the war on cancer. Nat. Rev. Cancer 2005, 5, 65. [CrossRef] [PubMed]

2. He, Q.; Shi, J. MSN Anti-cancer nanomedicines: Chemotherapy enhancement, overcoming of drug resistance, and metastasis inhibition. Adv. Mater. 2014, 26, 391-411. [CrossRef] [PubMed]

3. Tian, G.; Zheng, X.; Zhang, X.; Yin, W.; Yu, J.; Wang, D.; Zhang, Z.; Yang, X.; Gu, Z.; Zhao, Y. TPGS-stabilized $\mathrm{NaYbF}_{4}:$ Er upconversion nanoparticles for dual-modal fluorescent/CT imaging and anticancer drug delivery to overcome multi-drug resistance. Biomaterials 2015, 40, 107-116. [CrossRef] [PubMed]

4. Zhu, H.; Chen, H.; Zeng, X.; Wang, Z.; Zhang, X.; Wu, Y.; Gao, Y.; Zhang, J.; Liu, K.; Liu, R.; et al. Co-delivery of chemotherapeutic drugs with vitamin E TPGS by porous PLGA nanoparticles for enhanced chemotherapy against multi-drug resistance. Biomaterials 2014, 35, 2391-2400. [CrossRef] [PubMed]

5. Newhauser, W.D.; de Gonzalez, A.B.; Schulte, R.; Lee, C. A review of radiotherapy-induced late effects research after advanced technology treatments. Front. Oncol. 2016, 6, 13. [CrossRef] [PubMed]

6. Adams, M.J.; Lipsitz, S.R.; Colan, S.D.; Tarbell, N.J.; Treves, S.T.; Diller, L.; Greenbaum, N.; Mauch, P.; Lipshultz, S.E. Cardiovascular status in long-term survivors of hodgkin's disease treated with chest radiotherapy. J. Clin. Oncol. 2004, 22, 3139-3148. [CrossRef] [PubMed]

7. Darby, S.C.; Ewertz, M.; McGale, P.; Bennet, A.M.; Blom-Goldman, U.; Brønnum, D.; Correa, C.; Cutter, D.; Gagliardi, G.; Gigante, B.; et al. Risk of ischemic heart disease in women after radiotherapy for breast cancer. N. Engl. J. Med. 2013, 368, 987-998. [CrossRef] [PubMed]

8. Yu, M.; Zheng, J. Clearance pathways and tumor targeting of imaging nanoparticles. ACS Nano 2015, 9, 6655-6674. [CrossRef] [PubMed]

9. Albanese, A.; Tang, P.S.; Chan, W.C.W. The effect of nanoparticle size, shape, and surface chemistry on biological systems. Annu. Rev. Biomed. Eng. 2012, 14, 1-16. [CrossRef] [PubMed]

10. Maeda, H.; Nakamura, H.; Fang, J. The EPR effect for macromolecular drug delivery to solid tumors: Improvement of tumor uptake, lowering of systemic toxicity, and distinct tumor imaging in vivo. Adv. Drug Deliv. Rev. 2013, 65, 71-79. [CrossRef] [PubMed]

11. Nakamura, Y.; Mochida, A.; Choyke, P.L.; Kobayashi, H. Nanodrug delivery: Is the enhanced permeability and retention effect sufficient for curing cancer? Bioconjug. Chem. 2016, 27, 2225-2238. [CrossRef] [PubMed]

12. Torchilin, V.P. Recent advances with liposomes as pharmaceutical carriers. Nat. Rev. Drug Discov. 2005, 4, 145. [CrossRef] [PubMed]

13. Malam, Y.; Loizidou, M.; Seifalian, A.M. Liposomes and nanoparticles: Nanosized vehicles for drug delivery in cancer. Trends Pharmacol. Sci. 2009, 30, 592-599. [CrossRef] [PubMed]

14. Im, N.R.; Kim, K.M.; Young, S.J.; Park, S.N. Physical characteristics and in vitro skin permeation of elastic liposomes loaded with caffeic acid-hydroxypropyl- $\beta$-cyclodextrin. Korean J. Chem. Eng. 2016, 33, 2738-2746. [CrossRef]

15. Noh, G.Y.; Suh, J.Y.; Park, S.N. Ceramide-based nanostructured lipid carriers for transdermal delivery of isoliquiritigenin: Development, physicochemical characterization, and in vitro skin permeation studies. Korean J. Chem. Eng. 2017, 34, 400-406. [CrossRef] 
16. Rapoport, N. Physical stimuli-responsive polymeric micelles for anti-cancer drug delivery. Prog. Polym. Sci. 2007, 32, 962-990. [CrossRef]

17. Kakizawa, Y.; Kataoka, K. Block copolymer micelles for delivery of gene and related compounds. Adv. Drug Deliv. Rev. 2002, 54, 203-222. [CrossRef]

18. Iyer, A.K.; Greish, K.; Seki, T.; Okazaki, S.; Fang, J.; Takeshita, K.; Maeda, H. Polymeric micelles of zinc protoporphyrin for tumor targeted delivery based on EPR effect and singlet oxygen generation. J. Drug Target. 2007, 15, 496-506. [CrossRef] [PubMed]

19. Elsabahy, M.; Wooley, K.L. Design of polymeric nanoparticles for biomedical delivery applications. Chem. Soc. Rev. 2012, 41, 2545-2561. [CrossRef] [PubMed]

20. Kumari, A.; Yadav, S.K.; Yadav, S.C. Biodegradable polymeric nanoparticles based drug delivery systems. Colloids Surf. B 2010, 75, 1-18. [CrossRef] [PubMed]

21. Zahedi, P.; Fallah-Darrehchi, M.; Nadoushan, S.A.; Aeinehvand, R.; Bagheri, L.; Najafi, M. Morphological, thermal and drug release studies of poly (methacrylic acid)-based molecularly imprinted polymer nanoparticles immobilized in electrospun poly ( $\varepsilon$-caprolactone) nanofibers as dexamethasone delivery system. Korean J. Chem. Eng. 2017, 34, 2110-2118. [CrossRef]

22. Bianco, A.; Kostarelos, K.; Prato, M. Applications of carbon nanotubes in drug delivery. Curr. Opin. Chem. Biol. 2005, 9, 674-679. [CrossRef] [PubMed]

23. Liu, Z.; Tabakman, S.; Welsher, K.; Dai, H. Carbon nanotubes in biology and medicine: In vitro and in vivo detection, imaging and drug delivery. Nano Res. 2009, 2, 85-120. [CrossRef] [PubMed]

24. Kim, H.; Lee, D.; Kim, J.; Kim, T.-I.; Kim, W.J. Photothermally triggered cytosolic drug delivery via endosome disruption using a functionalized reduced graphene oxide. ACS Nano 2013, 7, 6735-6746. [CrossRef] [PubMed]

25. Wei, G.; Yan, M.; Dong, R.; Wang, D.; Zhou, X.; Chen, J.; Hao, J. Covalent modification of reduced graphene oxide by means of diazonium chemistry and use as a drug-delivery system. Chem. Eur. J. 2012, 18, 14708-14716. [CrossRef] [PubMed]

26. Chen, Y.-W.; Chen, P.-J.; Hu, S.-H.; Chen, I.W.; Chen, S.-Y. NIR-triggered synergic photo-chemothermal therapy delivered by reduced graphene oxide/carbon/mesoporous silica nanocookies. Adv. Funct. Mater. 2014, 24, 451-459. [CrossRef]

27. Ghosh, P.; Han, G.; De, M.; Kim, C.K.; Rotello, V.M. Gold nanoparticles in delivery applications. Adv. Drug Deliv. Rev. 2008, 60, 1307-1315. [CrossRef] [PubMed]

28. Brown, S.D.; Nativo, P.; Smith, J.-A.; Stirling, D.; Edwards, P.R.; Venugopal, B.; Flint, D.J.; Plumb, J.A.; Graham, D.; Wheate, N.J. Gold nanoparticles for the improved anticancer drug delivery of the active component of oxaliplatin. J. Am. Chem. Soc. 2010, 132, 4678-4684. [CrossRef] [PubMed]

29. Torchilin, V.P. Multifunctional, stimuli-sensitive nanoparticulate systems for drug delivery. Nat. Rev. Drug Discov. 2014, 13, 813-827. [CrossRef] [PubMed]

30. Veiseh, O.; Gunn, J.W.; Zhang, M. Design and fabrication of magnetic nanoparticles for targeted drug delivery and imaging. Adv. Drug Deliv. Rev. 2010, 62, 284-304. [CrossRef] [PubMed]

31. Sun, C.; Lee, J.S.H.; Zhang, M. Magnetic nanoparticles in MR imaging and drug delivery. Adv. Drug Deliv. Rev. 2008, 60, 1252-1265. [CrossRef] [PubMed]

32. Kazemi, S.; Sarabi, A.A.; Abdouss, M. Synthesis and characterization of magnetic molecularly imprinted polymer nanoparticles for controlled release of letrozole. Korean J. Chem. Eng. 2016, 33, 3289-3297. [CrossRef]

33. Zhao, N.; Wu, B.; Hu, X.; Xing, D. NIR-triggered high-efficient photodynamic and chemo-cascade therapy using caspase-3 responsive functionalized upconversion nanoparticles. Biomaterials 2017, 141, 40-49. [CrossRef] [PubMed]

34. Liu, J.-N.; Bu, W.; Pan, L.-M.; Zhang, S.; Chen, F.; Zhou, L.; Zhao, K.-L.; Peng, W.; Shi, J. Simultaneous nuclear imaging and intranuclear drug delivery by nuclear-targeted multifunctional upconversion nanoprobes. Biomaterials 2012, 33, 7282-7290. [CrossRef] [PubMed]

35. Liu, G.; Liu, N.; Zhou, L.; Su, Y.; Dong, C.-M. NIR-responsive polypeptide copolymer upconversion composite nanoparticles for triggered drug release and enhanced cytotoxicity. Polym. Chem. 2015, 6, 4030-4039. [CrossRef]

36. Yang, Y.; Velmurugan, B.; Liu, X.; Xing, B. NIR photoresponsive crosslinked upconverting nanocarriers toward selective intracellular drug release. Small 2013, 9, 2937-2944. [CrossRef] [PubMed] 
37. Yang, Y.; Liu, F.; Liu, X.; Xing, B. NIR light controlled photorelease of siRNA and its targeted intracellular delivery based on upconversion nanoparticles. Nanoscale 2013, 5, 231-238. [CrossRef] [PubMed]

38. Lee, S.; Lin, M.; Lee, A.; Park, Y. Lanthanide-doped nanoparticles for diagnostic sensing. Nanomaterials 2017, 7, 411. [CrossRef] [PubMed]

39. Weissleder, R. A clearer vision for in vivo imaging. Nat. Biotechnol. 2001, 19, 316-317. [CrossRef] [PubMed]

40. Li, C.; Liu, J.; Alonso, S.; Li, F.; Zhang, Y. Upconversion nanoparticles for sensitive and in-depth detection of $\mathrm{Cu}^{2+}$ ions. Nanoscale 2012, 4, 6065-6071. [CrossRef] [PubMed]

41. Shi, J.; Wang, L.; Zhang, J.; Ma, R.; Gao, J.; Liu, Y.; Zhang, C.; Zhang, Z. A tumor-targeting near-infrared laser-triggered drug delivery system based on GO@Ag nanoparticles for chemo-photothermal therapy and X-ray imaging. Biomaterials 2014, 35, 5847-5861. [CrossRef] [PubMed]

42. Auzel, F. Upconversion and anti-Stokes processes with $\mathrm{f}$ and $\mathrm{d}$ ions in solids. Chem. Rev. 2004, 104, 139-174. [CrossRef] [PubMed]

43. Li, H.; Hao, S.; Yang, C.; Chen, G. Synthesis of multicolor core/shell NaLuF $4: \mathrm{Yb}^{3+} / \mathrm{Ln}^{3+} @ \mathrm{CaF}_{2}$ Upconversion nanocrystals. Nanomaterials 2017, 7, 34. [CrossRef] [PubMed]

44. Bestvater, F.; Spiess, E.; Stobrawa, G.; Hacker, M.; Feurer, T.; Porwol, T.; Berchner-Pfannschmidt, U.; Wotzlaw, C.; Acker, H. Two-photon fluorescence absorption and emission spectra of dyes relevant for cell imaging. J. Microsc. 2002, 208, 108-115. [CrossRef] [PubMed]

45. Ahn, H.-Y.; Yao, S.; Wang, X.; Belfield, K.D. Near-infrared-emitting squaraine dyes with high 2PA cross-sections for multiphoton fluorescence imaging. ACS Appl. Mater. Interfaces 2012, 4, 2847-2854. [CrossRef] [PubMed]

46. Li, C.; Quan, Z.; Yang, J.; Yang, P.; Lin, J. Highly uniform and monodisperse $\beta-\mathrm{NaYF}_{4}: \operatorname{Ln}^{3+}(\mathrm{Ln}=\mathrm{Eu}, \mathrm{Tb}$, $\mathrm{Yb} / \mathrm{Er}$, and $\mathrm{Yb} / \mathrm{Tm}$ ) hexagonal microprism crystals: Hydrothermal synthesis and luminescent properties. Inorg. Chem. 2007, 46, 6329-6337. [CrossRef] [PubMed]

47. Haase, M.; Schäfer, H. Upconverting nanoparticles. Angew. Chem. Int. Ed. 2011, 50, 5808-5829. [CrossRef] [PubMed]

48. Tian, G.; Yin, W.; Jin, J.; Zhang, X.; Xing, G.; Li, S.; Gu, Z.; Zhao, Y. Engineered design of theranostic upconversion nanoparticles for tri-modal upconversion luminescence/magnetic resonance/X-ray computed tomography imaging and targeted delivery of combined anticancer drugs. J. Mater. Chem. B 2014, 2, 1379-1389. [CrossRef]

49. He, L.; Feng, L.; Cheng, L.; Liu, Y.; Li, Z.; Peng, R.; Li, Y.; Guo, L.; Liu, Z. Multilayer dual-polymer-coated upconversion nanoparticles for multimodal imaging and serum-enhanced gene delivery. ACS Appl. Mater. Interfaces 2013, 5, 10381-10388. [CrossRef] [PubMed]

50. Jo, H.L.; Song, Y.H.; Park, J.; Jo, E.-J.; Goh, Y.; Shin, K.; Kim, M.-G.; Lee, K.T. Fast and background-free three-dimensional (3D) live-cell imaging with lanthanide-doped upconverting nanoparticles. Nanoscale 2015, 7, 19397-19402. [CrossRef] [PubMed]

51. Wilhelm, S.; Hirsch, T.; Patterson, W.M.; Scheucher, E.; Mayr, T.; Wolfbeis, O.S. Multicolor upconversion nanoparticles for protein conjugation. Theranostics 2013, 3, 239-248. [CrossRef] [PubMed]

52. Boyer, J.-C.; van Veggel, F.C.J.M. Absolute quantum yield measurements of colloidal $\mathrm{NaYF}_{4}: \mathrm{Er}^{3+}, \mathrm{Yb}^{3+}$ upconverting nanoparticles. Nanoscale 2010, 2, 1417-1419. [CrossRef] [PubMed]

53. Wisser, M.D.; Fischer, S.; Maurer, P.C.; Bronstein, N.D.; Chu, S.; Alivisatos, A.P.; Salleo, A.; Dionne, J.A. Enhancing quantum yield via local symmetry distortion in lanthanide-based upconverting nanoparticles. ACS Photonics 2016, 3, 1523-1530. [CrossRef]

54. Liu, H.; Xu, C.T.; Lindgren, D.; Xie, H.; Thomas, D.; Gundlach, C.; Andersson-Engels, S. Balancing power density based quantum yield characterization of upconverting nanoparticles for arbitrary excitation intensities. Nanoscale 2013, 5, 4770-4775. [CrossRef] [PubMed]

55. Chen, W.; Chen, M.; Zang, Q.; Wang, L.; Tang, F.; Han, Y.; Yang, C.; Deng, L.; Liu, Y.-N. NIR light controlled release of caged hydrogen sulfide based on upconversion nanoparticles. Chem. Commun. 2015, 51, 9193-9196. [CrossRef] [PubMed]

56. Dong, Y.; Jin, G.; Ji, C.; He, R.; Lin, M.; Zhao, X.; Li, A.; Lu, T.J.; Xu, F. Non-invasive tracking of hydrogel degradation using upconversion nanoparticles. Acta Biomater. 2017, 55, 410-419. [CrossRef] [PubMed] 
57. Chen, G.; Shen, J.; Ohulchanskyy, T.Y.; Patel, N.J.; Kutikov, A.; Li, Z.; Song, J.; Pandey, R.K.; Ågren, H.; Prasad, P.N.; et al. $\left(\alpha-\mathrm{NaYbF}_{4}: \mathrm{Tm}^{3+}\right) / \mathrm{CaF}_{2}$ core/shell nanoparticles with efficient near-infrared to near-infrared upconversion for high-contrast deep tissue bioimaging. ACS Nano 2012, 6, 8280-8287. [CrossRef] [PubMed]

58. Michael Dcona, M.; Yu, Q.; Capobianco, J.A.; Hartman, M.C.T. Near infrared light mediated release of doxorubicin using upconversion nanoparticles. Chem. Commun. 2015, 51, 8477-8479. [CrossRef] [PubMed]

59. Chien, Y.-H.; Chou, Y.-L.; Wang, S.-W.; Hung, S.-T.; Liau, M.-C.; Chao, Y.-J.; Su, C.-H.; Yeh, C.-S. Near-infrared light photocontrolled targeting, bioimaging, and chemotherapy with caged upconversion nanoparticles in vitro and in vivo. ACS Nano 2013, 7, 8516-8528. [CrossRef] [PubMed]

60. Li, J.; Lee, W.Y.-W.; Wu, T.; Xu, J.; Zhang, K.; Hong Wong, D.S.; Li, R.; Li, G.; Bian, L. Near-infrared light-triggered release of small molecules for controlled differentiation and long-term tracking of stem cells in vivo using upconversion nanoparticles. Biomaterials 2016, 110, 1-10. [CrossRef] [PubMed]

61. Zhao, H.; Hu, W.; Ma, H.; Jiang, R.; Tang, Y.; Ji, Y.; Lu, X.; Hou, B.; Deng, W.; Huang, W.; et al. Photo-induced charge-variable conjugated polyelectrolyte brushes encapsulating upconversion nanoparticles for promoted siRNA release and collaborative photodynamic therapy under NIR light irradiation. Adv. Funct. Mater. 2017, 27, 1702592. [CrossRef]

62. Liu, C.; Zhang, Y.; Liu, M.; Chen, Z.; Lin, Y.; Li, W.; Cao, F.; Liu, Z.; Ren, J.; Qu, X. A NIR-controlled cage mimicking system for hydrophobic drug mediated cancer therapy. Biomaterials 2017, 139, 151-162. [CrossRef] [PubMed]

63. Yan, B.; Boyer, J.-C.; Branda, N.R.; Zhao, Y. Near-infrared light-triggered dissociation of block copolymer micelles using upconverting nanoparticles. J. Am. Chem. Soc. 2011, 133, 19714-19717. [CrossRef] [PubMed]

64. Wong, P.T.; Tang, S.; Cannon, J.; Chen, D.; Sun, R.; Lee, J.; Phan, J.; Tao, K.; Sun, K.; Chen, B.; et al. Photocontrolled release of doxorubicin conjugated through a thioacetal photocage in folate-targeted nanodelivery systems. Bioconjug. Chem. 2017, 28, 3016-3028. [CrossRef] [PubMed]

65. Zhang, L.; Lu, Z.; Bai, Y.; Wang, T.; Wang, Z.; Chen, J.; Ding, Y.; Yang, F.; Xiao, Z.; Ju, S.; et al. PEGylated denatured bovine serum albumin modified water-soluble inorganic nanocrystals as multifunctional drug delivery platforms. J. Mater. Chem. B 2013, 1, 1289-1295. [CrossRef]

66. Bertrand, O.; Gohy, J.-F. Photo-responsive polymers: Synthesis and applications. Polym. Chem. 2017, 8, 52-73. [CrossRef]

67. Jiang, J.; Tong, X.; Morris, D.; Zhao, Y. Toward photocontrolled release using light-dissociable block copolymer micelles. Macromolecules 2006, 39, 4633-4640. [CrossRef]

68. Aujard, I.; Benbrahim, C.; Gouget, M.; Ruel, O.; Baudin, J.-B.; Neveu, P.; Jullien, L. o-Nitrobenzyl photolabile protecting groups with red-shifted absorption: Syntheses and uncaging cross-sections for one- and two-photon excitation. Chem. Eur. J. 2006, 12, 6865-6879. [CrossRef] [PubMed]

69. Gargas, D.J.; Chan, E.M.; Ostrowski, A.D.; Aloni, S.; Altoe, M.V.P.; Barnard, E.S.; Sanii, B.; Urban, J.J.; Milliron, D.J.; Cohen, B.E.; et al. Engineering bright sub-10-nm upconverting nanocrystals for single-molecule imaging. Nat. Nanotechnol. 2014, 9, 300-305. [CrossRef] [PubMed]

70. He, S.; Krippes, K.; Ritz, S.; Chen, Z.; Best, A.; Butt, H.-J.; Mailander, V.; Wu, S. Ultralow-intensity near-infrared light induces drug delivery by upconverting nanoparticles. Chem. Commun. 2015, 51, 431-434. [CrossRef] [PubMed]

71. San Miguel, V.; Álvarez, M.; Filevich, O.; Etchenique, R.; del Campo, A. Multiphoton reactive surfaces using ruthenium(II) photocleavable cages. Langmuir 2012, 28, 1217-1221. [CrossRef] [PubMed]

72. Meng, Z.; Luan, L.; Kang, Z.; Feng, S.; Meng, Q.; Liu, K. Histidine-enriched multifunctional peptide vectors with enhanced cellular uptake and endosomal escape for gene delivery. J. Mater. Chem. B 2017, 5, 74-84. [CrossRef]

73. Park, J.S.; Park, W.; Park, S.-J.; Larson, A.C.; Kim, D.-H.; Park, K.-H. Multimodal Magnetic Nanoclusters for Gene Delivery, Directed Migration, and Tracking of Stem Cells. Adv. Funct. Mater. 2017, 27, 1700396. [CrossRef]

74. Tiberio, G.; Muccioli, L.; Berardi, R.; Zannoni, C. How does the trans-cis photoisomerization of azobenzene take place in organic solvents? ChemPhysChem 2010, 11, 1018-1028. [CrossRef] [PubMed]

75. Sierocki, P.; Maas, H.; Dragut, P.; Richardt, G.; Vögtle, F.; De Cola, L.; Brouwer, F.; Zink, J.I. Photoisomerization of azobenzene derivatives in nanostructured silica. J. Phys. Chem. B. 2006, 110, 24390-24398. [CrossRef] [PubMed] 
76. Ikeda, T.; Tsutsumi, O. Optical switching and image storage by means of azobenzene liquid-crystal films. Science 1995, 268, 1873-1875. [CrossRef] [PubMed]

77. Bandara, H.M.D.; Burdette, S.C. Photoisomerization in different classes of azobenzene. Chem. Soc. Rev. 2012, 41, 1809-1825. [CrossRef] [PubMed]

78. Huang, Y.; Dong, R.; Zhu, X.; Yan, D. Photo-responsive polymeric micelles. Soft Matter 2014, 10, 6121-6138. [CrossRef] [PubMed]

79. Yao, C.; Wang, P.; Li, X.; Hu, X.; Hou, J.; Wang, L.; Zhang, F. Near-infrared-triggered azobenzene-liposome/upconversion nanoparticle hybrid vesicles for remotely controlled drug delivery to overcome cancer multidrug resistance. Adv. Mater. 2016, 28, 9341-9348. [CrossRef] [PubMed]

80. Liu, J.; Bu, W.; Pan, L.; Shi, J. NIR-triggered anticancer drug delivery by upconverting nanoparticles with integrated azobenzene-modified mesoporous silica. Angew. Chem. Int. Ed. 2013, 52, 4375-4379. [CrossRef] [PubMed]

81. Chen, G.; Ma, B.; Xie, R.; Wang, Y.; Dou, K.; Gong, S. NIR-induced spatiotemporally controlled gene silencing by upconversion nanoparticle-based siRNA nanocarrier. J. Control. Release 2018, 282, 148-155. [CrossRef] [PubMed]

82. Hao, W.; Liu, D.; Wang, Y.; Han, X.; Xu, S.; Liu, H. Dual-stimuli responsive nanoparticles (UCNP-CD@APP) assembled by host-guest interaction for drug delivery. Colloids Surf. A 2018, 537, 446-451. [CrossRef]

83. Cui, L.; Zhang, F.; Wang, Q.; Lin, H.; Yang, C.; Zhang, T.; Tong, R.; An, N.; Qu, F. NIR light responsive core-shell nanocontainers for drug delivery. J. Mater. Chem. B 2015, 3, 7046-7054. [CrossRef]

84. Yao, C.; Wang, P.; Zhou, L.; Wang, R.; Li, X.; Zhao, D.; Zhang, F. Highly biocompatible zwitterionic phospholipids coated upconversion nanoparticles for efficient bioimaging. Anal. Chem. 2014, 86, 9749-9757. [CrossRef] [PubMed]

85. Hu, Q.-D.; Tang, G.-P.; Chu, P.K. Cyclodextrin-based host-guest supramolecular nanoparticles for delivery: From design to applications. Acc. Chem. Res. 2014, 47, 2017-2025. [CrossRef] [PubMed]

86. Mei, X.; Yang, S.; Chen, D.; Li, N.; Li, H.; Xu, Q.; Ge, J.; Lu, J. Light-triggered reversible assemblies of azobenzene-containing amphiphilic copolymer with $\beta$-cyclodextrin-modified hollow mesoporous silica nanoparticles for controlled drug release. Chem. Commun. 2012, 48, 10010-10012. [CrossRef] [PubMed]

87. Tomatsu, I.; Hashidzume, A.; Harada, A. Contrast viscosity changes upon photoirradiation for mixtures of poly(acrylic acid)-based $\alpha$-cyclodextrin and azobenzene polymers. J. Am. Chem. Soc. 2006, 128, 2226-2227. [CrossRef] [PubMed]

88. Yan, H.; Teh, C.; Sreejith, S.; Zhu, L.; Kwok, A.; Fang, W.; Ma, X.; Nguyen, K.T.; Korzh, V.; Zhao, Y. Functional mesoporous silica nanoparticles for photothermal-controlled drug delivery in vivo. Angew. Chem. Int. Ed. 2012, 51, 8373-8377. [CrossRef] [PubMed]

89. Moller, N.; Hellwig, T.; Stricker, L.; Engel, S.; Fallnich, C.; Ravoo, B.J. Near-infrared photoswitching of cyclodextrin-guest complexes using lanthanide-doped $\mathrm{LiYF}_{4}$ upconversion nanoparticles. Chem. Commun. 2017, 53, 240-243. [CrossRef] [PubMed]

90. Xu, J.; Xu, L.; Wang, C.; Yang, R.; Zhuang, Q.; Han, X.; Dong, Z.; Zhu, W.; Peng, R.; Liu, Z. Near-Infrared-Triggered Photodynamic Therapy with Multitasking Upconversion Nanoparticles in Combination with Checkpoint Blockade for Immunotherapy of Colorectal Cancer. ACS Nano 2017, 11, 4463-4474. [CrossRef] [PubMed]

91. Chi, Y.; Wenxing, W.; Peiyuan, W.; Mengyao, Z.; Xiaomin, L.; Fan, Z. Near-Infrared Upconversion Mesoporous Cerium Oxide Hollow Biophotocatalyst for Concurrent $\mathrm{pH}-/ \mathrm{H}_{2} \mathrm{O}_{2}$-Responsive $\mathrm{O}_{2}$-Evolving Synergetic Cancer Therapy. Adv. Mater. 2018, 30, 1704833. [CrossRef]

92. Han, Y.; An, Y.; Jia, G.; Wang, X.; He, C.; Ding, Y.; Tang, Q. Theranostic micelles based on upconversion nanoparticles for dual-modality imaging and photodynamic therapy in hepatocellular carcinoma. Nanoscale 2018, 10, 6511-6523. [CrossRef] [PubMed]

93. Gulzar, A.; Xu, J.; Xu, L.; Yang, P.; He, F.; Yang, D.; An, G.; Ansari, M.B. Redox-responsive UCNPs-DPA conjugated NGO-PEG-BPEI-DOX for imaging-guided PTT and chemotherapy for cancer treatment. Dalton Trans. 2018, 47, 3921-3930. [CrossRef] [PubMed] 
94. Bazylińska, U.; Wawrzyńczyk, D. Encapsulation of TOPO stabilized $\mathrm{NaYF}_{4}: \mathrm{Er}^{3+}, \mathrm{Yb}^{3+}$ nanoparticles in biocompatible nanocarriers: Synthesis, optical properties and colloidal stability. Colloids Surf. A 2017, 532, 556-563. [CrossRef]

95. Bazylińska, U.; Wawrzyńczyk, D.; Kulbacka, J.; Frąckowiak, R.; Cichy, B.; Bednarkiewicz, A.; Samoć, M.; Wilk, K.A. Polymeric nanocapsules with up-converting nanocrystals cargo make ideal fluorescent bioprobes. Sci. Rep. 2016, 6, 29746. [CrossRef] [PubMed]

(c)

(C) 2018 by the authors. Licensee MDPI, Basel, Switzerland. This article is an open access article distributed under the terms and conditions of the Creative Commons Attribution (CC BY) license (http:/ / creativecommons.org/licenses/by/4.0/). 